\title{
Evidence of Competition Between Two Canopy Ant Species: Is Aggressive Behavior Innate or Shaped by a Competitive Environment?
}

\author{
Nádia Barbosa do Espírito Santo, ${ }^{1,2}$ Sérvio Pontes Ribeiro, ${ }^{3}$ \\ and Juliane Floriano Santos Lopes ${ }^{1}$ \\ ${ }^{1}$ Programa de Pós-Graduação em Comportamento e Biologia Animal, Universidade Federal de Juiz de Fora, \\ Campus Universitário Martelos, 36036-330 Juiz de Fora, MG, Brazil \\ ${ }^{2}$ Programa de Pós-Graduação em Ecologia, Universidade Estadual de Campinas, 13083-970 Campinas, SP, Brazil \\ ${ }^{3}$ Departamento de Biodiversidade, Evolução e Meio Ambiente, Programa de Pós-Graduação em Ecologia de Biomas Tropicais, \\ Universidade Federal de Ouro Preto, Campus Morro do Cruzeiro, 35400-000 Ouro Preto, MG, Brazil
}

Correspondence should be addressed to Nádia Barbosa do Espírito Santo, nadiabarbosa@yahoo.com.br

Received 1 June 2011; Accepted 4 July 2011

Academic Editor: Jonathan D. Majer

Copyright (c) 2012 Nádia Barbosa do Espírito Santo et al. This is an open access article distributed under the Creative Commons Attribution License, which permits unrestricted use, distribution, and reproduction in any medium, provided the original work is properly cited.

Competition occurs in all ecological communities, although it has not always been experimentally tested as a structuring force in the distribution of species. We tested the hypothesis that the aggressiveness exhibited by Camponotus rufipes changes according to the pressures of a competitive environment. This is a dominant species in the montane forest of the Itacolomi State Park, Brazil, where Camponotus sericeiventris does not occur. Using bait traps in a field site where both species occur, ("Juiz de Fora" site) we showed that $C$. sericeiventris was able to remove $C$. rufipes workers at the same bait. In the laboratory, we used dyadic encounters to test workers from both species taken from colonies found in areas where both occur and where only C. rufipes was found. Camponotus rufipes from Itacolomi fought significantly less and was killed during the first few minutes in $60 \%$ of the events. On the other hand, the workers that co-existed with $C$. sericeiventris in the field were more aggressive, but less efficient fighters than the latter. This investigation demonstrated existence of competition between C. rufipes and C. sericeiventris, and also the lower aggressiveness of C. rufipes' individuals that did not co-exist in the field with C. sericeiventris.

\section{Introduction}

The importance of competition for structuring ecological communities is a matter for debate, and it has been extensively researched in ant assemblages [1]. Exploitation and interference competition in ants involve mutual aggression, which can frequently be observed, often resulting in injuries, death, and the avoidance of one colony by another [1]. The more similar are the species' morphology and niche breadths, the stronger is the competition $[2,3]$. Species coexistence is possible when there are diversified strategies for resource usage, namely, time partitioning, feeding-source differentiation, or nesting locations $[1,3]$. On the other hand, competition causes hierarchical dominance amongst the species through the use of aggression, food source exclusion, and different foraging strategies $[4,5]$. Dominant ant species can influence the occurrence of other species and play a major role in ant assemblage structuring, in which they generate distribution patterns and a mosaic-like species coexistence, especially in forest canopies [6-9].

Territorial defence is related to dominance and occurs widely among canopy ant species in tropical rainforests [5]. Here, we observe the occurrence of a hierarchical competition that is based on their social organization and, ultimately, on foraging workers density. Hence, when a nonterritorial species encounter a territorial one, the former tends to run way from aggressive conflict, which may result in locally improbable species pairs $[10,11]$. 
Camponotus (Myrmothrix) rufipes (Fabricius, 1775) is normally associated with ecotones between forests and open vegetation and is rarely found in great quantities in the canopy of lowland forests [12-18]. However, in the State Park of Itacolomi, a montane forest ecosystem in the borders between the Brazilian Cerrado and the Atlantic rainforest, this species is the most frequent member of this genus in the canopy [18]. In this particular forest the potential competitor, Camponotus (Myrmepomis) sericeiventris (GuérinMenéville, 1838), which has a similar body size and uses the same kinds of food and nesting sites, was absent, unlike in the other areas of Atlantic rainforest and in most other Neotropical arboreal ecosystems [19]. On the contrary of $C$. rufipes, the latter is mostly frequent and dominant in the upper canopy $[19,20]$.

The present work investigates the degree of $C$. rufipes aggressiveness in contrasting competitive environments by means of direct observation in field and laboratory. We tested the hypothesis that $C$. rufipes shows different behaviours depending on the nature of the competitive environment. The prediction is that levels of aggressiveness of C. rufipes vary in response to presence or absence of competition from C. sericeiventris.

\section{Methods}

2.1. Field Experiments. Observations were carried out at two locations in the Atlantic rainforest. The first was Itacolomi State Park (Itacolomi), Minas Gerais State $\left(20^{\circ} 22^{\prime} 30^{\prime \prime} \mathrm{S}\right.$ and $43^{\circ} 32^{\prime} 30^{\prime \prime} \mathrm{W}$ ), between $1000-1300$ metres above sea level, within an area of 7.543 hectares, and belonging to the Espinhaço Mountain Range, which has a tropical montane climate, with rainfall varying from 1000 to $1500 \mathrm{~mm}$ per year and the temperatures between $4^{\circ} \mathrm{C}$ and $33^{\circ} \mathrm{C}$ [21]; The second was the campus of the Federal University of Juiz de Fora (UFJF) $\left(21^{\circ} 46^{\prime} 47^{\prime \prime} \mathrm{S}\right.$ and $\left.43^{\circ} 22^{\prime} 24^{\prime \prime} \mathrm{W}\right)$, at 818 metres above sea level, also with a well-defined rainy and dry seasons, an annual average temperature of $19.3^{\circ} \mathrm{C}$, and a annual precipitation of $1500 \mathrm{~mm}$ [22]. Both species, C. rufipes and $C$. sericeiventris, were encountered at the UFJF campus, but only $C$. rufipes was found in Itacolomi.

At Itacolomi, three trees were selected because of the high foraging activity of previously observed C. rufipes ants [18]. At the UFJF Campus, three trees were also selected in a territorial border where both C. rufipes and C. sericeiventris coexisted: in two of the trees there was an intense foraging by C. rufipes ants, due to the existence of nests closer than 10 metres to their trunk; in the third, there was a C. sericeiventris nest. The experiments were conducted during the months of October and November 2007.

Observations were made on one tree per day, thus in 3 days all trees were observed. Afterwards, two new rounds of observations, following the same order, were executed. Hence, in 9 days all trees were observed three times, with 2 days intervals between each observation. As the experiment was conducted within a short and continuous time interval, no relevant change in weather conditions was noticed. On the trunks of each of these trees a paper towel with attractant bait made of sardines $(10 \mathrm{~g})$ and honey $(1: 1 ; \mathrm{g}: \mathrm{g})$ was placed. The behavioural recordings started with the arrival of the first C. rufipes ant in Itacolomi, whereas at the UFJF Campus it started when the first $C$. rufipes or $C$. sericeiventris appeared. From that moment on, we used the sequential sampling method [23]. For 4 hours, during five minutes at 10-minute intervals, all ant behaviours were recorded. These recordings include not only the behaviour of the two species in focus but also that of all the other species that appeared. Hence, this experiment was composed of six behavioural recordings per tree, constituting 18 repetitions, that provided 288 records. The observed behavioural acts were then divided into three categories: action, reaction, and nonaggressive.

Access to the tree crowns was achieved by tree-trunk climbing, either with or without a rope, and using safety equipment (see Ribeiro et al. [24]). Contingency tables were created to analyse species superiority in aggressiveness for both action and reaction types of behaviour. The analyses were done using Chi-square at a 5\% significance level.

2.2. Laboratory Experiments. Experimental dyadic encounters were manipulated between C. rufipes and C. sericeiventris workers from different colonies collected in both Itacolomi and UFJF. Approximately 70 workers of C. rufipes from an Itacolomi colony were collected. Meanwhile, 50 workers of this species, along with 50 workers of C. sericeiventris, were collected from UFJF in an area where they coexisted. These collected ants were kept in a lidded plastic containers $(12 \mathrm{~cm} \times 9 \mathrm{~cm})$ with a cotton ball soaked in water-diluted honey and remained isolated (at $25^{\circ} \mathrm{C}$ and $70 \%$ humidity) for 24 hours before performing the experiment. During this period, the samples were exposed to similar stress of collecting and travelling, and subsequent resting in the laboratory. The resting period and the experiments took place at the Myrmecology Laboratory of UFJF during the months of December 2007 and January 2008.

At each dyadic encounter, two ants of the same caste were placed in an arena ( $6 \mathrm{~cm}$ diameter) with Fluon at the edges to prevent their escape. To relieve the stress of transferring, the ants were separated by a partition in the arena for 10 minutes. Afterwards, the partition was removed, and their behaviour was registered during 5 minutes (ad libitum [23]). The observed behavioural acts were divided into three categories: action, reaction, and nonaggressive.

We manipulated six types of encounters (Table 1) and each one was repeated 10 times. After each repetition, the experimental arena was cleaned with alcohol 50\% to eliminate any ant odour, so as to not interfere with the results of the next repetition. For the repetitions involving ants of the same species, the individuals were marked on the pronotum with nontoxic ink using an Edding 750 pen [25].

Aggression was calculated according to a modified index of aggressiveness from Errard and Hefetz [26]. The assigned values represent degrees of aggressiveness: $0=$ "touched antennae and retreated", 1 = "on alert and charged", 2 = "bite", 3 = "torsioned gaster" and 4 = "fight". The resulting index for each treatment was subjected to the Kruskall-Wallis test, followed by the post-hoc Student-Newman-Keuls test, at $5 \%$ significance level (Table 2), using Biostat 4.0 software. This study was performed under licence permission from 
TABle 1: Dyadic encounters occurring at the laboratory of the Federal University of Juiz de Fora (UFJF) for all treatments and species involved.

\begin{tabular}{lcc}
\hline & Treatment & Species \\
\hline 1 & Control C. rufipes Itacolomi & C. rufipes Itacolomi $\times$ C. rufipes Itacolomi \\
2 & Control C. rufipes UFJF & C. rufipes UFJF $\times$ C. rufipes UFJF \\
3 & Control C. sericeiventris UFJF & C. sericeiventris UFJF $\times$ C. sericeiventris UFJF \\
4 & Neighbours & C. rufipes UFJF $\times$ C. sericeiventris UFJF \\
5 & Same species & C. rufipes UFJF $\times$ C. rufipes Itacolomi \\
6 & Different species & C. rufipes Itacolomi $\times$ C. sericeiventris UFJF \\
\hline
\end{tabular}

Itacolomi = Itacolomi State Park; UFJF = Campus of the Federal University of Juiz de Fora.

Table 2: Student-Newman-Keuls $(H=77.1648)$ comparisions for each treatment of dyadic encounters listed in Table 1 (significative $P$ values in evidence).

\begin{tabular}{|c|c|c|c|c|c|c|c|}
\hline & & $\begin{array}{c}1 \\
\text { Control } \\
\text { C. rufipes } \\
\text { Itacolomi }\end{array}$ & $\begin{array}{c}2 \\
\text { Control } \\
\text { C. rufipes UFJF }\end{array}$ & $\begin{array}{c}3 \\
\text { Control } \\
\text { C. sericeiventris } \\
\text { UFJF }\end{array}$ & $\begin{array}{c}4 \\
\text { Neighbours }\end{array}$ & Same species & $\begin{array}{c}6 \\
\text { Different species }\end{array}$ \\
\hline 1 & $\begin{array}{c}\text { Control } C . \\
\text { rufipes Itacolomi }\end{array}$ & - & $0.0031^{*}$ & 0.7043 & $<0.0001^{*}$ & $<0.0001^{*}$ & 0.4172 \\
\hline 2 & $\begin{array}{l}\text { Control } C . \\
\text { rufipes UFJF }\end{array}$ & & - & $0.0008^{*}$ & 0.0344 & 0.0355 & $0.0002^{*}$ \\
\hline 3 & $\begin{array}{l}\text { Control } C \text {. } \\
\text { sericeiventris } \\
\text { UFJF }\end{array}$ & & & - & $<0.0001^{*}$ & $<0.0001^{*}$ & 0.6659 \\
\hline 4 & Neighbours & & & & - & 0.9891 & $<0.0001^{*}$ \\
\hline 5 & Same species & & & & & - & $<0.0001^{*}$ \\
\hline 6 & Different species & & & & & & - \\
\hline
\end{tabular}

Itacolomi: Itacolomi State Park; UFJF: Campus of the Federal University of Juiz de Fora.

the State Forestry Institute, and it followed university's ethic requirements for experiments with alive animals.

\section{Results}

3.1. Field Experiments. Nine morphospecies of ants were registered in experiments conducted in the Itacolomi State Park and 12 in the UFJF Campus. Fourteen types of behaviours were registered with the bait. The behaviour exhibited by the ants is categorized and described in Table 3.

The most frequent behaviours for the ants in the two experimental sites were "quietly feeding" and "exploring the surroundings" (Table 4). When observing interactive behaviour in Itacolomi, C. rufipes was the species that most engaged in the aggressive actions of "charge" and "bite" $\left(\chi^{2}=88.3, P<0.001\right)$. Myrmelachista sp. 1 was the one that most engaged the reactions of "flee" and "gaster torsion" $\left(\chi^{2}=15.65, P<0.05\right)$ (Figure 1$)$. For all the other species together, only two registers were recorded for the "charge" behaviour, while the "avoid", "flee", and "retreat" were the most frequent ones $\left(\chi^{2}=15.65, P<0.05\right)$, suggesting that they were submissive to the aggressiveness of $C$. rufipes.

In UFJF campus, C. rufipes and C. sericeiventris frequently showed aggressive behaviour through the actions of "charge" and "bite" $\left(\chi^{2}=45.78, P<0.05\right)$ with no statistical difference between these species in terms of the amount of these acts performed $\left(\chi^{2}=3.43, P>0.05\right)$. All other morphospecies showed significantly more defensive behaviour, especially "retreat" and "flee" reactions $\left(\chi^{2}=18.9, P<0.05\right)$ (Figure 2).

When comparing behaviour of C. rufipes workers from the two sites, the UFJF individuals bit more than the Itacolomi individuals, which showed more of "avoid" aggressors act $\left(\chi^{2}=19.34, P<0.05\right)$ (Figure 3$)$. Concerning reaction behaviours, the C. rufipes from the UFJF colony tended to "retreat", especially in the presence of $C$. sericeiventris $\left(\chi^{2}=23.9, P<0.05\right)$ (Figure 2$)$.

3.2. Laboratory Experiments. Fifteen types of behaviours were registered in the laboratory, which are categorized and described in Table 3. According to the calculated aggressiveness index, the more aggressive encounters were between C. rufipes workers from the two areas and between $C$. rufipes from Itacolomi and $C$. sericeiventris, thus, between workers whose colonies are far apart from each other (Figure 4). Colony workers had an average agonistic response significantly larger than that observed between themselves in the control experiment (Table 2).

Considering the mortality at the encounters, we verified that $70 \%$ of $C$. rufipes workers were dead in less than 2 
Table 3: Description of behavioral acts displayed by the ants on Itacolomi State Park (Itacolomi) and the Campus of Federal University of Juiz de Fora (UFJF) during field experiments $\left({ }^{* *}\right)$ and laboratory experiments (dyadic encounters) occurring at the lab of the Federal University of Juiz de Fora $(*)$.

\begin{tabular}{|c|c|c|}
\hline Action & Reaction & Nonaggressive \\
\hline $\begin{array}{l}\text { Charge-an ant approaches the other with } \\
\text { its mandible open }\end{array}$ & $\begin{array}{l}(* *) \text { Remain on the bait-after any types of } \\
\text { the listed actions, the ant remains in the } \\
\text { area, eating the bait }\end{array}$ & $\begin{array}{l}(* *) \text { Quietly eating-when an ant is } \\
\text { standing still, only eating the bait }\end{array}$ \\
\hline $\begin{array}{l}\text { Bite-grips part of the body of another } \\
\text { individual with its mandibles }\end{array}$ & $\begin{array}{l}(* *) \text { Flee-after any types of these actions it } \\
\text { flees not only from the area, but also from } \\
\text { the bait }\end{array}$ & $\begin{array}{l}(* *) \text { Food transport-the individual carries } \\
\text { part of the bait to the colony }\end{array}$ \\
\hline $\begin{array}{l}\text { Espontaneous gaster torsion-the ant curls } \\
\text { its abdomen to emits formic acid }\end{array}$ & $\begin{array}{l}\left({ }^{*}\right) \text { Retreat-after the mentioned actions, } \\
\text { it retreats from the other individual, but } \\
\text { does not leave the bait and eats it }\end{array}$ & Autogrooming_cleaning itself \\
\hline $\begin{array}{l}\text { Avoid-when perceiving the proximity of } \\
\text { another individual, the first moves away, } \\
\text { avoiding the encounter }\end{array}$ & $\begin{array}{l}\text { Defensive gaster torsion-after these } \\
\text { actions, it exhibits aggressive behaviour by } \\
\text { curling its abdomen to emit formic acid }\end{array}$ & $\begin{array}{l}\text { Trophallaxis-exchange of regurgitated } \\
\text { liquid from one individual directly into the } \\
\text { crop of the other }\end{array}$ \\
\hline $\begin{array}{l}\left({ }^{*}\right) \text { Antennal touching-an ant exchanges } \\
\text { antennal touches with the other for } \\
\text { identification }\end{array}$ & $\begin{array}{l}\text { Fight-after mentioned actions, it grabs the } \\
\text { other individual with its jaws and emits } \\
\text { formic acid }\end{array}$ & $\begin{array}{l}\text { Exploring the surroundings-walking } \\
\text { around, touching its antennae on the whole } \\
\text { extension of the paper where the bait was } \\
\text { placed }\end{array}$ \\
\hline \multirow[t]{2}{*}{$\begin{array}{l}(*) \text { On alert-an ant stands still with its } \\
\text { head and antenna raised, and with its gaster } \\
\text { torsed in the posterior-anterior position } \\
\text { ready to emit formic acid, if necessary }\end{array}$} & $\begin{array}{l}(*) \text { Bite-grips part of the body of another } \\
\text { individual with its mandibles in response to } \\
\text { any action act }\end{array}$ & $\begin{array}{l}\left.{ }^{*}\right) \text { Trying to escape-the ant stays on the } \\
\text { border of the arena, trying to climb its wall }\end{array}$ \\
\hline & $\begin{array}{l}(*) \text { Charge-the ant advances in the } \\
\text { direction of the other with its mandible } \\
\text { open ready to bite back }\end{array}$ & \\
\hline
\end{tabular}

(*) Only in lab experiments; (**) Only in field experiments.

minutes (mostly in seconds) in the encounters between C. rufipes from Itacolomi and C. sericeiventris. (KruskalWallis, Student-Newman-Keuls $=23.12, P<0.035)$. For the remaining 30\%, C. rufipes killed C. sericeiventris in one case, and two other times there were fights without deaths.

Unlike the encounters with the neighbouring C. rufipes and $C$. sericeiventris from UFJF, the fight lasted longer and all the repetitions severally resulted in death; $60 \%$ of the $C$. sericeiventris and $40 \%$ of the C. rufipes died. It is worth noting that when C. rufipes were killed, the trial was faster than when it was not killed. Finally, in the treatment between C. rufipes from the two studied sites, the ants from the Itacolomi colony died in half of the repetitions without causing a single death among the ants from UFJF (Table 1).

\section{Discussion}

4.1. Field Experiments. Regardless of the advantage of aggressiveness, high costs of competing may mean that its selective advantage is only sustainable if associated with the minimization of conflicts. An evidence is that the behaviours most frequently exhibited by all ants species from both sites were "quietly feeding" and "exploring the surroundings". According to ethograms found in the literature, the most common behavioural acts are into the categories of grooming, feeding, and exploring surroundings [19, 27-29].

Likewise, the "dear enemy" hypothesis [30] predicts that ant species are capable of recognizing and discriminating their neighbours (species/individuals), and then they are normally more aggressive with the "foreigners", saving energy by avoiding unnecessary conflicts with species or colonies with which they have already defined their boundaries [31, 32]. The species that live together adjust to the habitat and share resources, while foreigners may threaten this balance [30]. In addition, the constant contact among all coexisting ants followed by autogrooming results in a common Gestalt odour, that decreases the aggressiveness among all the species that share the same space [4]. Finally, for canopy ants, it has been reported that various species have the habit of foraging over great distances, presenting familiarity with the place, and tolerating the presence of neighbour species [33].

Both experiments suggest that these species tend to have a territory which is aggressively protected, and thus are able to dominate numerically in the canopies. Both species seem to have defensive behavior across the complete territory, instead of only at the nest or some particular feeding resource, as aggressive actions have been observed everywhere in the studied forest (pers.obs.) and have been corroborated experimentally. The dominant position could be taken by $C$. rufipes where $C$. sericeiventris does not occur, while in the presence of the latter, C. rufipes may still keep high abundance (mainly by combining foraging in different habitats, such as the canopy and in the litter) and codominate the assemblage.

Concerning other observed species, distinct behaviours at the bait reflected their recruiting and foraging strategies and, in many cases, their attack and defence tactics. Many species proved to be opportunists, eating rapidly until being 


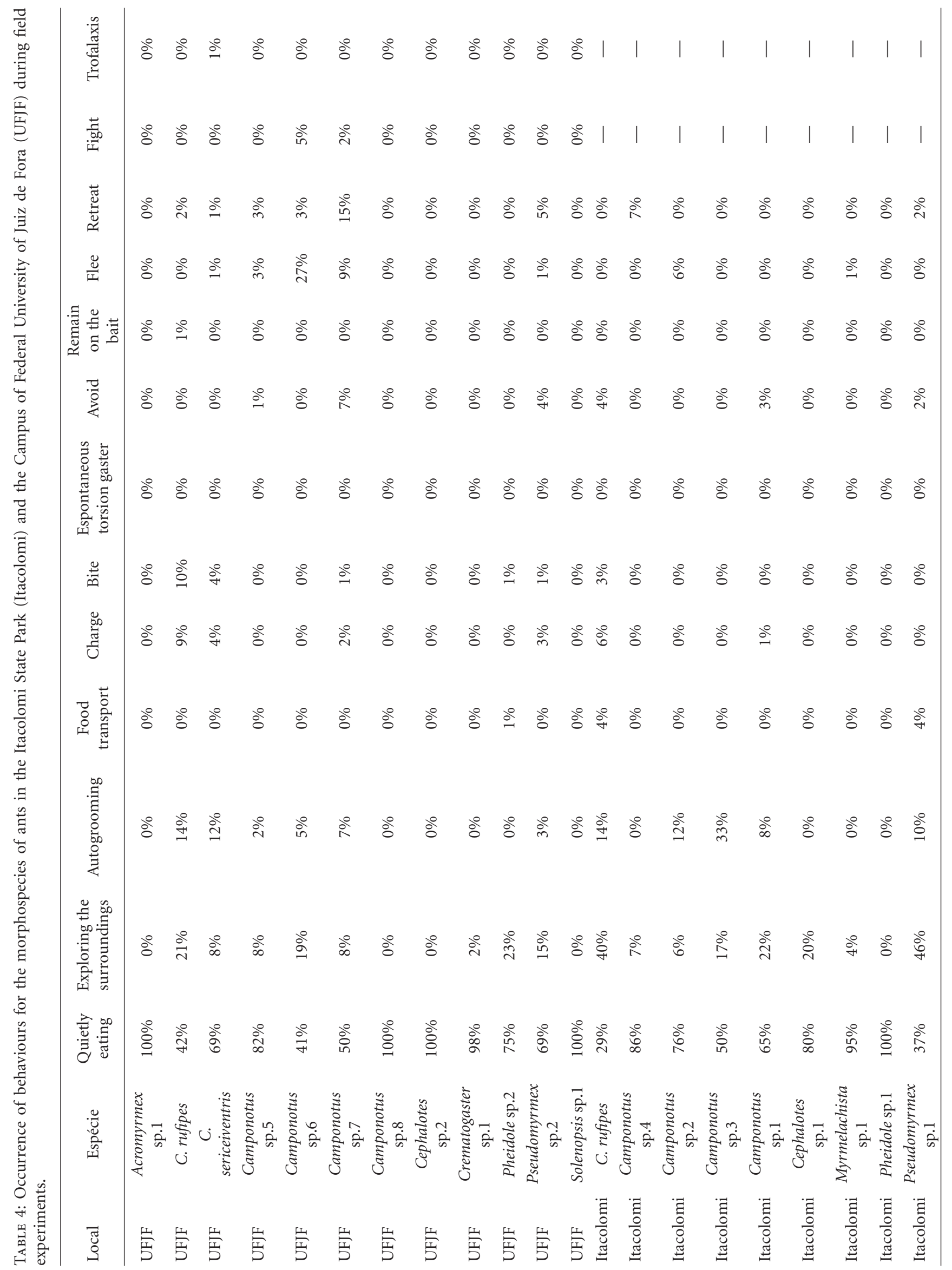




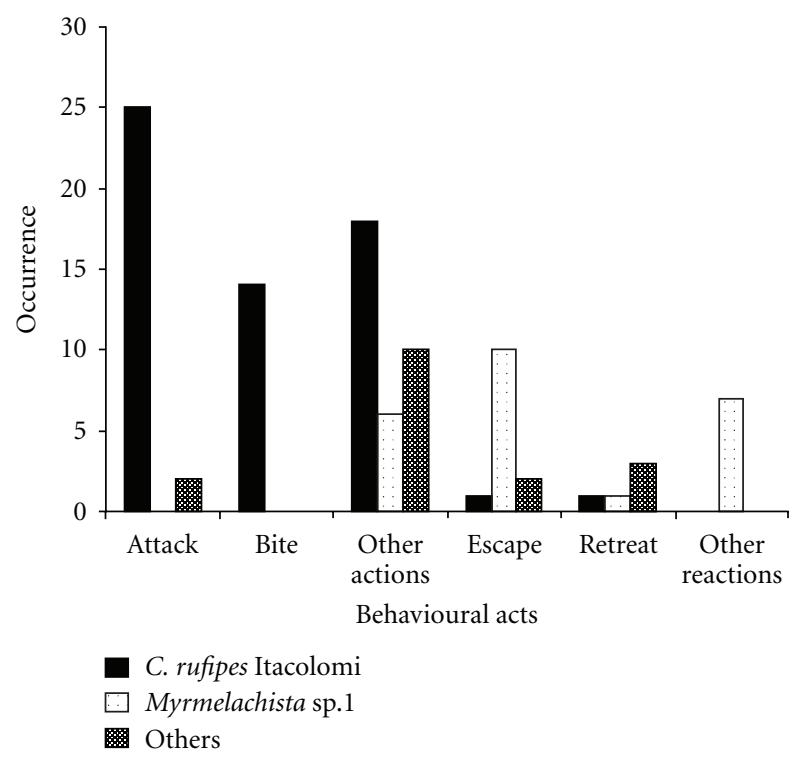

Figure 1: Action and reaction behavioural occurrences for $C$. rufipes, Myrmelachista sp.1 ants, and other morphospecies assemblages during field experiments in the Itacolomi State Park (Itacolomi). The "other actions" and "other reactions" are grouped together because of their low frequency.
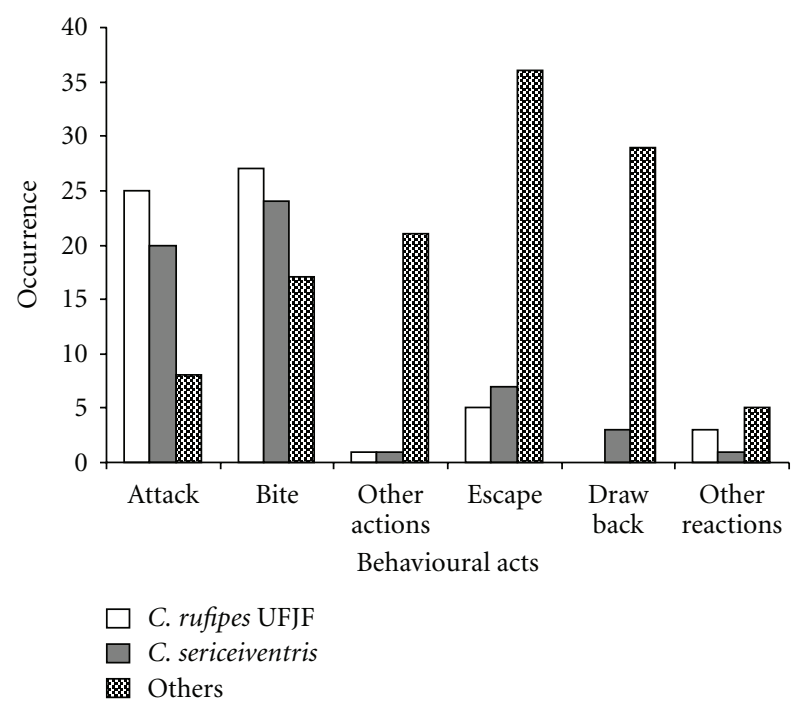

Figure 2: Action and reaction behavioural occurrences for $C$. rufipes, C. sericeiventris, and other morphospecies (grouped together) during field experiments at the Campus of Federal University of Juiz de Fora. The "other actions" and "other reactions" behaviours are grouped together because of their low frequency.

expelled by the dominant species, but avoiding interactive aggressive behaviour. In this study, the genera Cephalotes and Pseudomyrmex, along with some species of Camponotus (C. crassus and three nonidentified Camponotus species) exhibited this type of behaviour. The opportunistic or cowardly behaviour was previously recorded by Cephalotes pusillus in Byk and Del-Claro [34], as the species was never

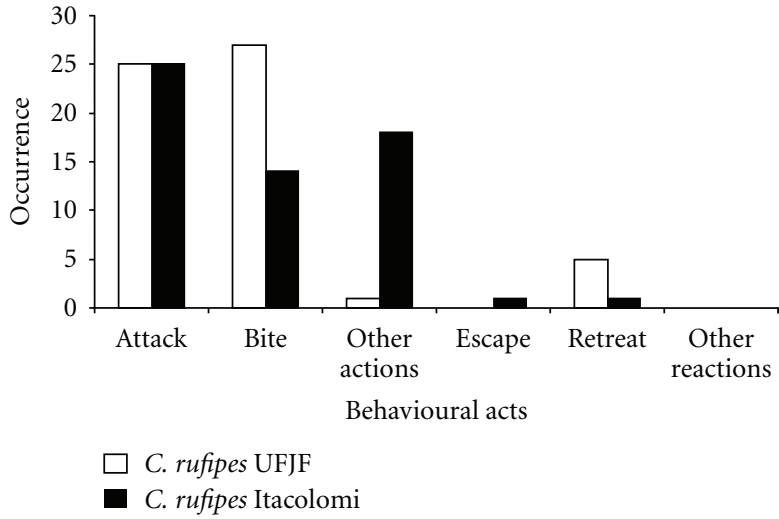

Figure 3: Action and reaction behavioural occurrences for the $C$. rufipes colonies at the Itacolomi State Park (Itacolomi) and campus of Federal University of Juiz de Fora (UFJF) during field experiments. The "other actions" and "other reactions" behaviours are grouped together because of their low frequency.

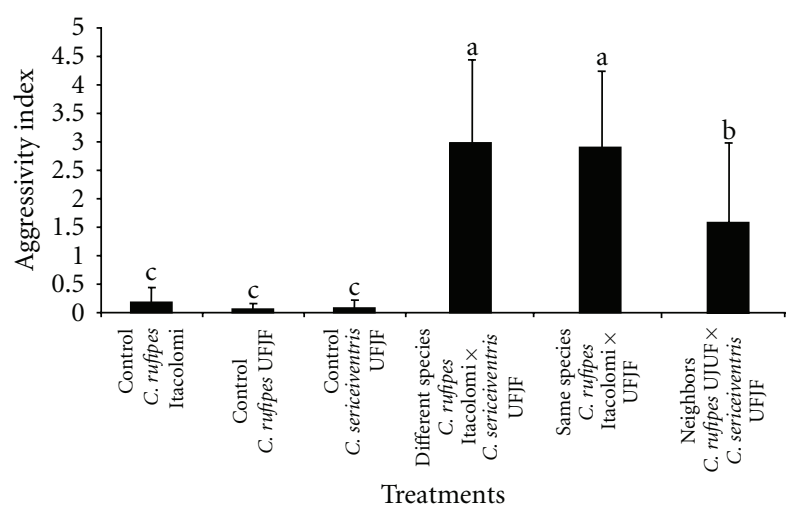

Figure 4: Aggressiveness index (mean and standard deviation) for each treatment of laboratory experiments (dyadic encounters) in which "control" is the manipulation with individuals from the same colony and species; "different species" between C. rufipes from Itacolomi State Park (Itacolomi) and C. sericeiventris from Campus of Federal University of Juiz de Fora (UFJF); "same species" between C. rufipes from both Itacolomi and UFJF; "neighbours" between $C$. rufipes and C. sericeiventris from UFJF.

observed attacking any insect, contrary to what is expected for a plan-ant-herbivore system.

To a certain extent, the coexistence of these species was possible due to behavioural diversity. For instance, we observed that different species place themselves almost opposite to the others when eating on the bait, thus avoiding conflicts while sharing the same resource at the same moment. In this study, at various times when the bait was exposed, there were around five ant species on it. An erroneous interpretation of this would be to say that there was no competition in place. However, upon behavioural observation in locu, it was evident that species placed themselves strategically on the bait, avoiding visual or chemical contact. Furthermore, when two species meet, there was aggressive behaviour, resulting in fleeing of one of them. It is worth noting, though, that 
since baits were an energetic, unpredictable, and sufficiently abundant food source, it was possible for various species to eat at the same time without the need to expel or attack the others. Most of natural resources available ought to result in a tougher competitive environment than the one we manipulated.

4.2. Laboratory Experiments. Camponotus rufipes and C. sericeiventris were able to recognize individuals of their colony and to differentiate them from other colonies and species. For C. rufipes, this capacity has already been registered [35]. Most importantly, the present experiment measured the aggressiveness between these species, which was high for C. sericeiventris, but also stronger for those individuals of C. rufipes that coexisted in the field with C. sericeniventris, compared with the Itacolomi's individuals. Since Itacolomi's ants have grown without any substantial competition in nature, they become pacifists.

Similar results were previously described for other systems. Lucas [36] observed three species of Pachycondyla ( $P$. villosa, $P$. inversa, and $P$. subversa) during dyadic encounters and found out that they were able to recognize members of the same colony, of the same species and of different species, increasing aggressiveness in the same order. For C. rufipes at UFJF, there was no differentiation of aggressiveness between intra- and interspecific encounters, which means that their defensive behaviour against $C$. sericeiventris or a potential invader colony of their own species was similar and may reflect their establishment in a hostile environment.

Combative behaviours are widely described in the myrmecological literature. In the laboratory, Oecophylla longinoda (a dominant arboreal genera) was observed while fighting for its territory with two foreign individuals that entered simultaneously the arena [37]. This species was also observed in its natural habitat fighting and excluding other ant colonies in Africa. Similar results were encountered for Oecophylla smaragdina in Australia [38, 39]. De Vita [40] measured the aggressiveness of Pogonomyrmex californicus populations in their natural habitat and observed that $81 \%$ of the encounters resulted in some type of aggression and, in some cases, led to the death of the individuals. In addition, there was evidence that ants of the same species from different colonies showed aggression against each other. Aggression was also shown against potential competitors of another species, which resulted in fights or death in all repetitions.

The lack of aggressiveness from Itacolomi's C. rufipes corroborates the assumption that aggressive behaviour is more likely learned than inherited, especially since the same species (C. rufipes from UFJF) that coexists with competitors presents a greater level of aggressiveness and a greater capacity to fight with foreign species of the same size ( $C$. rufipes from Itacolomi). Also, the data from the encounters among C. rufipes from Itacolomi and C. sericeiventris show that $C$. rufipes from Itacolomi was almost always attacked and killed. On the other hand, when the encounters were between C. rufipes and C. sericeiventris that coexisted in the same area (UFJF), the battles were more evensided, registering $40 \%$ of the deaths for workers of C. rufipes and $60 \%$ for
C. sericeiventris. In these cases, the aggressiveness index was higher; the ants fought for a longer time before one of them died. In the field experiments, there was no occurrence of a fight to death between $C$. rufipes and C. sericeiventris, as had occurred in the dyadic encounters. Nevertheless, a transposing experiment is needed to confirm whether such aggressiveness would be learnt or, otherwise, whether there could be a C. rufipes "pacifist genotype".

As generally observed in the field for all species, these two codominant species also avoid combative behaviour, in accordance with the prediction that a strategy of decreasing costs of combat is of great importance in behavioural evolution. This mutual avoidance during the field experiments could also be related to the abundance of food that the bait represents, which implies in no dispute. However, the dominant species was bothered by the presence of other species when they were encountered feeding at the same place in the bait. On the other hand, in the dyadic encounters in a small arena and with no escape route, the ants had no alternative other than to dispute that small space by attacking and killing the other individual.

In conclusion, direct contacts seem to be avoided between C. rufipes and C. sericeiventris, as is expected, since they are two species with similar feeding habits, nesting location, foraging strategy, and body dimensions. However, C. rufipes species from Itacolomi does not have a great fighting capacity, very likely because it does not coexist with any other similar competitor, showing that behavioural plasticity will always favour the cost-saving behaviour, namely avoiding conflict.

\section{Acknowledgments}

The authors thank Jacques H. C. Delabie, Fábio Prezoto, and Nathércia Espírito Santo for original paper revision; IEF, the State Institute of Forestry and the administration of Itacolomi State Park for providing permits and logistical facilities for the work. They thank FAPEMIG for financial support and Universidade Federal de Juiz de Fora for a masters grant. Sérvio Pontes Ribeiro is a researcher funded by CNPq.

\section{References}

[1] B. Hölldobler and E. O. Wilson, The Ants, The Belknap Press of Harvard University Press, Cambridge, Mass, USA, 1990.

[2] R. H. Macarthur and R. Levins, "The limiting similarity, convergence, and divergence of coexisting species," American Naturalist, vol. 101, pp. 377-385, 1967.

[3] N. J. Gotelli and A. M. Ellison, "Assembly rules for New England ant assemblages," Oikos, vol. 99, no. 3, pp. 591-599, 2002.

[4] E. O. Wilson, The Insect Societies, Harvard University Press, Cambridge, Mass, USA, 1971.

[5] D. W. Davidson, "Resource discovery versus resource domination in ants: a functional mechanism for breaking the tradeoff," Ecological Entomology, vol. 23, no. 4, pp. 484-490, 1998.

[6] P. M. Room, "The relative distribution of ant species in Ghana's cocoa farms," Journal of Animal Ecolog, vol. 40, pp. 735-751, 1971. 
[7] D. Leston, "The ant mosaic, tropical tree crops and the limiting of pests and diseases," Pest Articles and News Summaries, vol. 19, pp. 311-341, 1973.

[8] D. Leston, "A neotropical ant mosaic," Annals of the Entomological Society of America, vol. 71, pp. 649-653, 1978.

[9] J. D. Majer, J. H. C. Delabie, and M. R. B. Smith, "Arboreal ant community patterns in Brazilian cocoa farms," Biotropica, vol. 26, no. 1, pp. 73-83, 1994.

[10] B. Hölldobler and C. J. Lumsden, "Territorial strategies in ants," Science, vol. 210, no. 4471, pp. 732-739, 1980.

[11] R. Savolainen and K. Vepsalainen, "A competition hierarchy among boreal ants: impact on resource partitioning and community structure," Oikos, vol. 51, no. 2, pp. 135-155, 1988.

[12] K. Del-Claro and P. S. Oliveira, "Ant-homoptera interactions in a neotropical savanna: the honeydew-producing treehopper, Guayaquila xiphias (Membracidae), and its associated ant fauna on Didymopanax vinosum (Araliaceae)," Biotropica, vol. 31, no. 1, pp. 135-144, 1999.

[13] M. R. Orr, D. L. Dahlsten, and W. W. Benson, "Ecological interactions among ants in the genus Linepithema, their phorid parasitoids, and ant competitors," Ecological Entomology, vol. 28, no. 2, pp. 203-210, 2003.

[14] R. C. Fonseca and E. Diehl, "Riqueza de formigas (Hymenoptera: Formicidae) epigéicas em povoamentos de Eucalyptus spp. (Myrtaceae) de diferentes idades no Rio Grande do Sul, Brasil," Revista Brasileira de Entomologia, vol. 48, pp. 95-100, 2004.

[15] E. F. O. Peternelli, T. M. C. Della Lucia, and S. V. Martins, "Espécies de formigas que interagem com sementes de Mabea fistulifera Mart. (Euphorbiaceae)," Revista Árvore, vol. 28, pp. 733-738, 2004.

[16] J. A. Lutinski and F. R. M. Garcia, “Análise faunística de Formicidae (Hymenoptera: Apocrita) em ecossistema degradado no município de Chapecó, Santa Catarina," Biotemas, vol. 18, pp. 73-86, 2005.

[17] M. S. Santos, J. N. C. Louzada, N. Dias, R. Zanetti, J. H. C. Delabie, and I. C. Nascimento, "Litter ants richness (Hymenoptera, Formicidae) in remnants of a semi-deciduous forest in the Atlantic rain forest, Alto do Rio Grande region, Minas Gerais, Brazil," Iheringia, vol. 96, no. 1, pp. 95-101, 2006.

[18] N. B. Espírito Santo, Assembléia de formigas do Parque Estadual do Itacolomi (MG) e relações intra-e interespecíficas entre espécies dominantes, M.S. thesis, Pós-Graduação em Comportamento e Biologia Animal/Departamento de Biologia Animal/Universidade Federal de Juiz de Fora, 2008.

[19] M. Yamamoto and K. Del-Claro, "Natural history and foraging behavior of the carpenter ant Camponotus sericeiventris Guérin, 1838 (Formicinae, Campotonini) in the Brazilian tropical savanna," Acta Ethologica, vol. 11, no. 2, pp. 55-65, 2008.

[20] R. I. Campos, J. P. Scares, R. P. Martins, and S. P. Ribeiro, "Effect of habitat structure on ant assemblages (Hymenoptera: Formicidae) associated to two pioneer tree species," Sociobiology, vol. 47, no. 3, pp. 721-738, 2006.

[21] M. A. G. Fujaco, Influência dos diferentes tipos de substrato e geomorfologia na distribuição espacial e arquitetônica do gênero Eremanthus no Parque Estadual do Itacolomi, Ouro Preto/MG, M.S. thesis, Pós-Graduação em Evolução Crustal e Recursos Naturais/Departamento de Geologia/Universidade Federal de Ouro Preto, 2007.

[22] "Banco de dados climáticos do Brasil-Embrapa Monitoramento por Satélite e Esalq-USP,” 2007, http://www.bdclima .cnpm.embrapa.br/resultados/.
[23] J. Altmann, "Observational study of behavior: sampling methods," Behaviour, vol. 49, no. 3-4, pp. 227-267, 1974.

[24] S. P. Ribeiro, J. P. Soares, R. I. Campos, and R. P. Martins, "Insect herbivores species associated to pioneer tree species: contrasting within forest and ecotone canopy habitats," Revista Brasileira de Zoociências, vol. 10, pp. 237-248, 2008.

[25] J. F. S. Lopes, W. O. H. Hughes, R. S. Camargo, and L. C. Forti, "Larval isolation and brood care in Acromyrmex leaf-cutting ants," Insectes Sociaux, vol. 52, no. 4, pp. 333-338, 2005.

[26] C. Errard and A. Hefetz, "Label familiarity and discriminatory ability of ants reared in mixed groups," Insectes Sociaux, vol. 44, no. 3, pp. 189-198, 1997.

[27] J. C. Santos and K. Del-Claro, "Ecology and behaviour of the weaver ant Camponotus (Myrmobrachys) senex," Journal of Natural History, vol. 43, no. 23-24, pp. 1423-1435, 2009.

[28] C. R. Ferreira Brandão, "Sequential ethograms along colony development of Odontomachus affinis Guérin (Hymenoptera, Formicidae, Ponerinae)," Insectes Sociaux, vol. 30, no. 2, pp. 193-203, 1983.

[29] J. C. Santos, M. Yamamoto, F. R. Oliveira, and K. Del-Claro, "Behavioral repertory of the weaver ant Camponotus (Myrmobrachys) senex (Hymenoptera: Formicidae)," Sociobiology, vol. 46, no. 1, pp. 27-37, 2005.

[30] E. O. Wilson, Sociobiology, Belknap Press of Harvard University Press, Cambridge, Mass, USA, 1975.

[31] T. A. Langen, F. Tripet, and P. Nonacs, "The red and the black: habituation and the dear-enemy phenomenon in two desert Pheidole ants," Behavioral Ecology and Sociobiology, vol. 48, no. 4, pp. 285-292, 2000.

[32] T. Delsinne, Y. Roisin, and M. Leponce, "Spatial and temporal foraging overlaps in a Chacoan ground-foraging ant assemblage," Journal of Arid Environments, vol. 71, no. 1, pp. 29-44, 2007.

[33] C. R. Carroll and D. H. Janzen, "Ecology of foraging by ants," Annual Review of Ecology and Systematics, vol. 4, pp. 231-257, 1973.

[34] J. Byk and K. Del-Claro, "Nectar- and pollen-gathering Cephalotes ants provide no protection against herbivory: a new manipulative experiment to test ant protective capabilities," Acta Ethologica, vol. 13, no. 1, pp. 33-38, 2010.

[35] K. Jaffé and C. Sánchez, "On the nestmate-recognition system and territorial marking behaviour in the ant Camponotus rufipes," Insectes Sociaux, vol. 31, no. 3, pp. 302-315, 1984.

[36] C. Lucas, Étude des bases chimiques et comportamentales de la formation $d u$ "visa" colonial chez les Ponérines du genre Pachycondyla, Thèse Docteur, Biologie du Comportement, Universitè Paris XI, Paris, France, 2002.

[37] B. Hölldobler and E. O. Wilson, "The multiple recruitment systems of the african weaver ant Oecophylla longinoda (Latreille) (Hymenoptera: Formicidae)," Behavioral Ecology and Sociobiology, vol. 3, no. 1, pp. 19-60, 1978.

[38] B. Hölldobler, "Territoriality among Oecophylla," National Geographic Society Research Reports, vol. 1977, pp. 369-372, 1979.

[39] B. Hölldobler, "Territorial behavior in the green tree ant (Oecophylla smaragdina)," Biotropica, vol. 15, pp. 241-250, 1983.

[40] J. De Vita, "Mechanisms of interference and foraging among colonies of the harvester ant Pogonomyrmex californcus in the Mojave Desert," Ecology, vol. 60, pp. 729-737, 1979. 

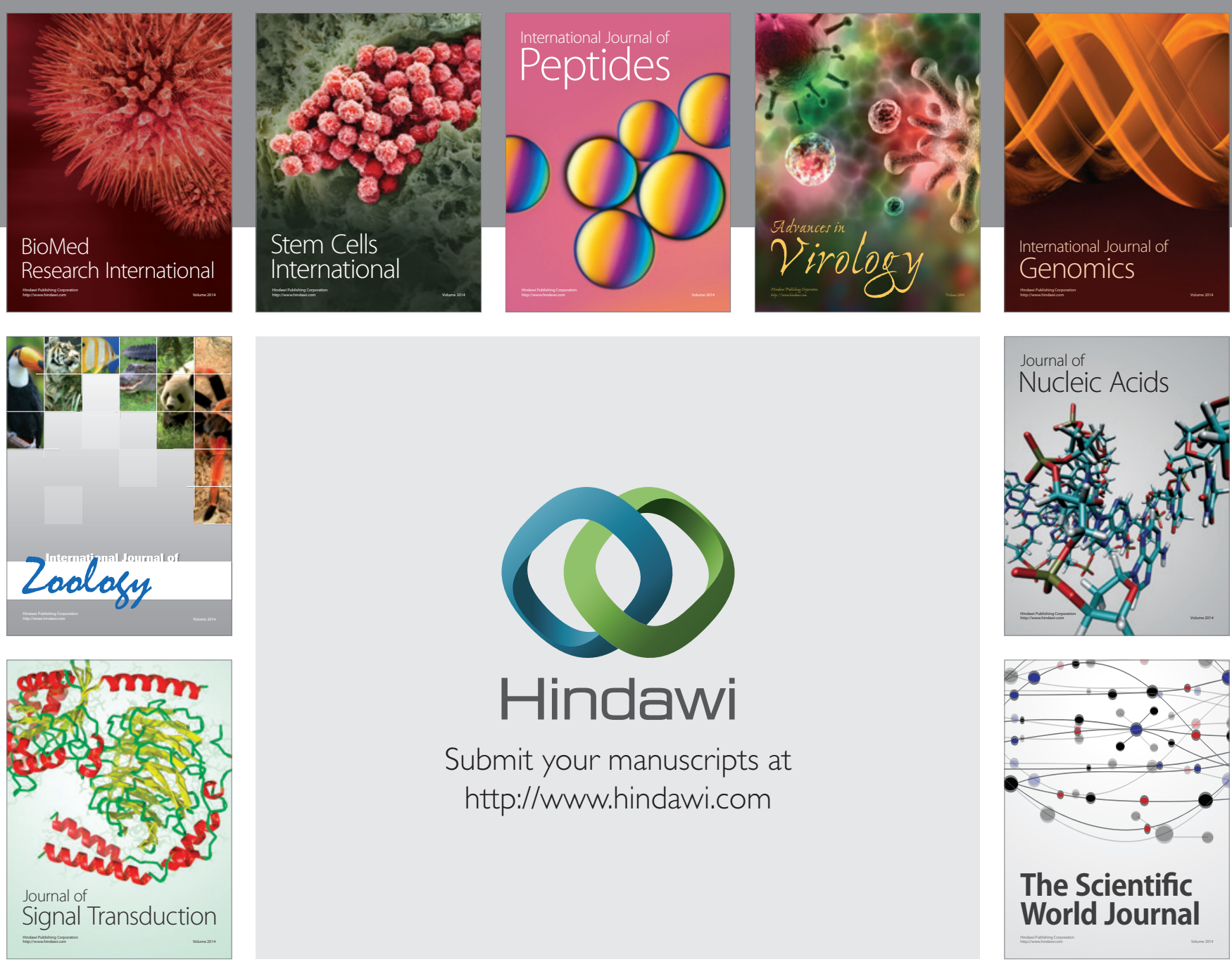

Submit your manuscripts at

http://www.hindawi.com
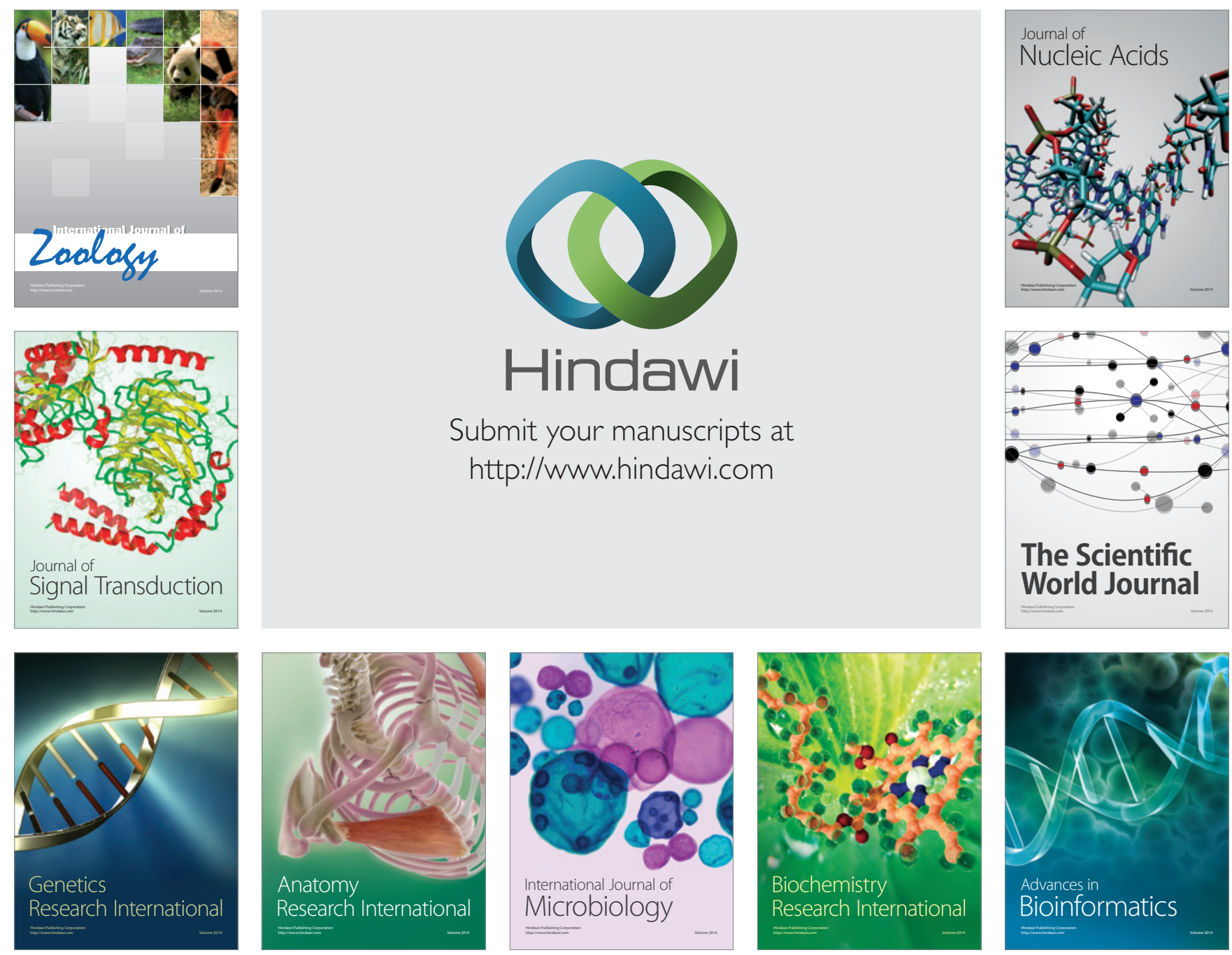

The Scientific World Journal
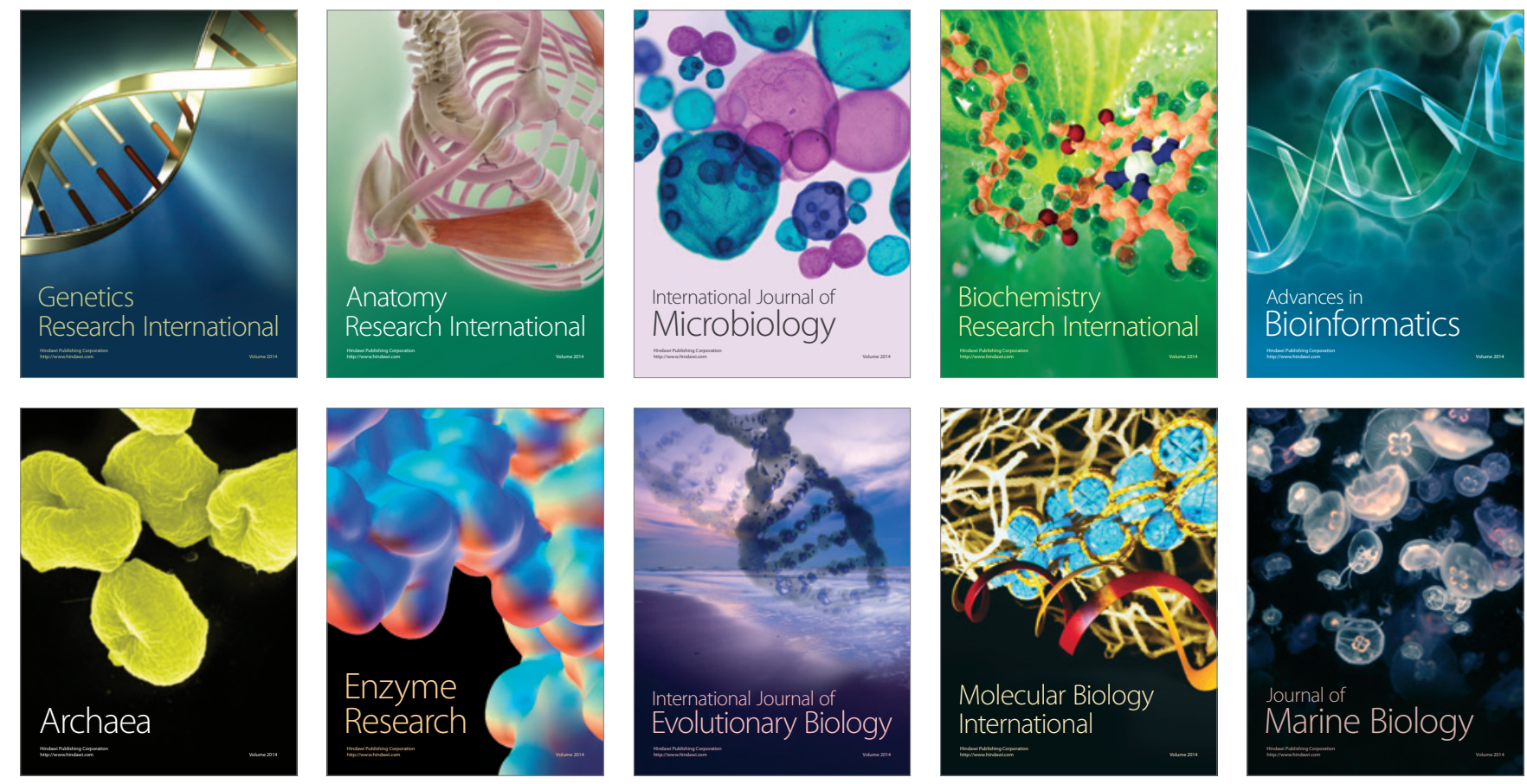